\title{
On Fast Cruizers
}

\section{Sir Edward J. Reed K.C.B., F.R.S., M.P.}

To cite this article: Sir Edward J. Reed K.C.B., F.R.S., M.P. (1888) On Fast Cruizers, Royal United Services Institution. Journal, 32:145, 781-800, DOI: 10.1080/03071848809416491

To link to this article: http://dx.doi.org/10.1080/03071848809416491

\section{曲 Published online: 11 Sep 2009.}

Submit your article to this journal

LII Article views: 3

Q View related articles $\sqsubset$ 
Friday, Juno 29, 1888. ADMIRAL Sir EDIVARD G. FANSHAWE, G.C.B., Vice-President,
in the Chair.

\section{ON FAST CRUIZERS.}

\section{By Sir Edirard J. REed, K.C.B., F.R.S., M.P.}

Ox the 26th of Norember, 1884, I had tho honour of reading a paper at this Institution, by tho request of its Council, in which 1 gave the best ansirer in ing poirer to the question put to me by tho Council, viz., "What aro the most urgent measures that should be taken for increasing Her Majesty's NarJ?"

Although the subject for to-day's discussion is of a much more liwited character, it mas perhaps be well for me to mention on tuy way to it that there is great cause, I think, for congratulation in this Iustitution upon the consequeuces of the $188 \pm$ discussion in some inportant respects.

Une instance may be fonnd in the total change that lins come over the ndministration of the $\Lambda$ dmiralty and of the dockyards in respect of the time occupied in building ships. That delays in completion due to want of guus are just as great now as erer, I am well aware, and our consequent weakness, and even dauger, which would be felt in the crent of war is well known to those hero assembled. Bat as regards the quick bailding and completion of new ships in Her Mlajesty's dockyards, the erils of which I complained at length in 1884 haro been terminated, and so great is the improrement effected that those two fine ironclads, tho "Nile" aud "Trafalgar," are to be finished in 1889 and 1890 respectively, although commenced only in 1886. I $\mathrm{nm}$ pleased to say tbat this improvement has not been attended by any ndditional expenditure of public mouey; on the contrars, the Committce of the Houso of Commons on Nars Estimates, which is now sitting (and at which I ought to be present at this moment), has received evidence which proves conclusively that the quicker construction of our ships is attended by the economiza. tion of our money to a rery large extent. It is not usual, I believe, and it is not neccssars, to pay compliments at theso meetings to the Jixecutivo Goverument; but as a political opponent of the present Gorernment I may perhaps be permitted to say that theso bencficial results are very largely due to two successive Secretaries to the $\Delta$ dmiralty scrving ander Isord George IJamilton, viz., Mrr. Ritchie, 
who introduced some of the ieforms, and $\mathrm{Mr}$. Forwood, who has in. troduced others, and has carricd them all forward with uncommou nbility and persererance. To Mr. Ligar, the new Director of Dockyards, wo owe the clever carrying out with technical skill and on bnsiness principles of the measures authorized by the Admiralty, and the initintion of others for further promoting efliciency and cconomy.

The "Nile" and "Trafalgar" are themsclecs cxamples of nnother great chnnge effected sinco 1884 -I menn the construction of renl, trustworthy, armoured line-of-battle ships fit to engage the enemy any where and at any time, in lien of the ships of the "Admiral "class and some others, the chief defence of which in battle must certninly be looked for clsenhere than in the partial strip of armour amidships rising but a few inches above the smooth-water's surface which alone has been nllowed them. I do not sas that I consider the "Nilo" and "Trafalgar" the hest possible ships; far from it. I could take exception to cert:in of their funtures if the necessity arose; but this is not the occasion for doing so, nor is it, in ms opiuion, nt all desirable to caril at and criticizo minor defects in Her Mfajesty's ships, prorided they are in the main rightly designed. It is only when great and dangerous crrors aro mado and persisted in that it becomes us to aronse ourselves; nnd thankful am I that, at length, after jears of contention and complaint, a stop has been put to the bailding of first-class armoured ships 80-called, with the armour on their sides so amazingly restricted in extent, as to leare the whole strncture, and all on board it, nn casj pros to a few light, quickfiring guns.

A third subject upon which we may congratnlate ourselves, I think, as a result following rery quickly upon our discussion of 188.1 , is the construction of faster ships for Her Arjesty's Navy thau had crer. hefore been designed. The progress in this respect has not been ncarly so satisfactory, as will presently be scen, as in respect of the other points then adrocated-quick ship-building, and the designing of our new ironclads with side-armour enough to defend them properly; but thero is no room to doubt that the discussion in question furnished the gencral basis of Irord Northbrook's additional programme, and greatly stimulated the production of fast vessels. The modo of carrying out tho prograwme has been far from satisfactory.

Als primary object in Friting this paper is to put a further check apon the lajing down of cruizers of insufticient speed, and to give a new stimulus to the construction of swift ones. It will help to illustrato and further these objects if wo briefly reriow what has happened in respect of cruizers since my former paper was read here.

Dealing with armoured cruizers first, it will be remembered that my advice to the Admiralts was to build forthwith fire large armourbelted cruizers of 8,000 tons, steaming 19 to $20 \mathrm{knots}$, to be "suppliad with abundant fuel," and costing 500,000l. cach fully completed. These cruizers would have had thick belts, rising 4 feet abore watcr all along the broad central parts of the ship to within 40 or. 50 fect 
of the stem and stern; they would hare had 15,000 ind. horse-power, and a norinal coal snipply of 1,000 tons, with the power to carry an extra supply of 500 tons in presence of the enemy, or of 800 tons (giving 1,800 tons in all) when grocecling abroad and not requiring to give battle. These objects could hnve been fulfilled with the proposed ressels of 8,0010 tons vormal displacement, and costing $500,000 l$.

The Board of Admiralty decided to build fire fnst armour-belted cruizers, as recommended, bat were advised to construct them of a kind very different indeed from that just described. T'hey fxed upon 5,040 tons displacement instead of 8,$000 ;$ a comparatively thin armour-belt; a belt so shallow that its total width mas only 5 fect, of which 4 fect were to be under, and $1 \frac{1}{2}$ feet abore water; a speed of 17 knots; an indicated engine-power of 7,500 ; and a coal supply of 500 tons. Thes were to cost (or are costing), when armed, nearly $300,000 l$. each. On the very face of these fgares it was wanifest that the ships thus projected never would or could fulfil the object which 1 had proposed, which sou had ardently supported in this hall, and which they rerc avowedly designed to fulfil. $\Lambda$ s soon as their intended character became known to me, I irrote to the "Times," nnd protested against their insufficient specd. The Admiralts then nunounced that thes should be made $17 \frac{1}{2}$-kuot vessels. I agitin protested in the "Tiunes," and a further concession was made; nore powerful engines (of 8,500 indicated horse-power) were ordered for tirem, and a speed of 18 knots was secured, the coal supply being reluced to 410 tons. I need not tronble jou with the whole story, $f: r$ it is fully and most frunkly recorded in the "Statement of the First Lord of the Admiralty explanatory of the Navy Litimates, 1837-88." The absurdity of giving to a fast armoured cruizcr (which obriously needed a much larger supply of fucl than an ordi. nary armoured ship) a supply less in proportion to its indicasted horsepower than had crer beforo been giren in our Navs was apparent to the present Board, and they decided that to be of use as cruizers theso ressels must be allowed to fill their bunkers (that had been made large for the purpose), and carrs 900 tons of coal ; and the net result of adopting so insufficieut a design in the first instance wias, in the lnnguage of Lord George Haruilton, this: "If the whole of the 900 tons, with the additiunnl weights alluded to, be placed on bonrd, instead of 410 tons, the top of the belt will be, on the ships first going to sea, 6 inches below the water." The fire ships of this kind hare been increased to seren in number, at an aggregate cost of orer $2,000,000 l$. 
Fia. 1.-Admiralts beltcd cruizcrs.

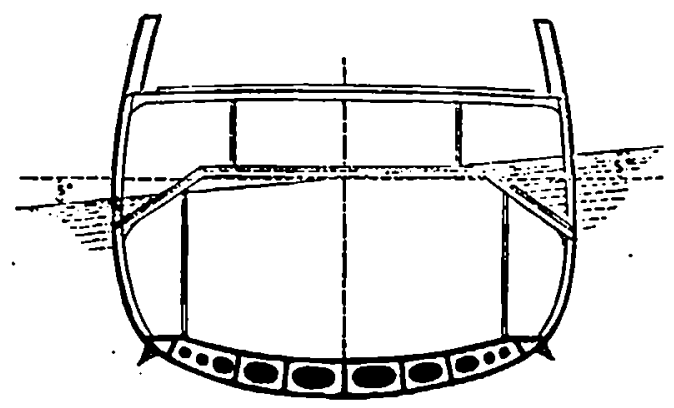

I necd not ask any naval Officer, or indeed any man of common sense, whether the two millions sterling which have been expended on these ressels have been rell expended. I vonture to belicre that in the discassion which is to follow the rending of this paper, not a single person will rise and say that the expenditure of the $2 \frac{1}{2}$ millious which I proposed, upon five 8,000-ton 20-knot cruizers such as I described just now, would not hare been rastly more raluable to the Navy than the expenditure which has in fact been incurred. It is true that the lirst Lord of the Admiralty, in the paper which I have quoted, tells us that " some persons claim" for the orer-immersion of these ships " certnin compensating ndvantages," aud upon these I must briefly remark, for they are very remarkable.

The first is that there will be abore the immersed armour-belt "a coal protection of $6 \frac{1}{2}$ feet in height and of 11 to $17 \mathrm{fcct}$ in repth." But surely this is a wew version of the "coal protection" doctrinc. Witherto wo havo been told that when armour protection could not be giren to engines and boilers the protection of coal would be better thau nothing, which is to a certain extent true. But this is a cas: in which the engines and boilers have alreads been protected by the armour-belt and thick deck, and that which has been left unprotected is the buojancy, the power to float; and how on carth, or rather on sea, a ship's power to keep afloat when wounded under water, or at the water-line, is promoted by putting some hundreds of tons of coal in her, or by its being already there, is more than I can tell or can imagine. 'T'be First Lord unst have taken this on trust, belicriug that, foolish as it seems, there must be some obscare reason for it. I must leave my hearcrs to judge whether the anonymous authors of this remarkable suggestion, which, as the Admiralty appear to accept nnd rels upon it, may lead to the sacrifice of several ships and many lires, deserro tho trust reposed in them, or whether their names should not be giren to the world as the authors of unheard of hydrostatic principles.

The sccond "compensating adrautage" is that "the coal protection will not be disturbed until, by the consumption of coal in the lower bunkers, the ship had lightened, and the armour-belt had risen above 
water." Renson and imagination aliko fail me in attempting to put any honcst meaning into theso words. How can it conceivally bo to the adrantage of these long finc-line, not too stable, ships that the engincers shall, under all circamstances, be compelled to burn the coal out of the bunkers below before they disturb this huge mass of coal above the armour deck? The First Lord sajs of this coal that it rues along 140 feet of its length, for $6 \frac{1}{2}$ feet in height and from 11 to 17 feet in deoth, say, of an arerage depth (measured transversely) of 14 feet. One snch block of conl would weigh orer 300 tons; blocks like this along both sides of the ship, which is probably what is meant, would weigh orer 600 tons. Their ceutre of gravity wonld be high up, at least 31 feet abore the load water-line, when the belt beran to emerge. Without calculating the stability of these ships, which I lanre not liad time to do, I decline to speak positively on the point; bat I put it to nautical men, who bnow that these ships aro 300 feet long and 56 brond, with 221 feet draught of water, and with water-lines of almost unexampled fineness, whether it docs not from tho outside of the subject look as if it were rather dangerous treatment in a sea-way for such a ship, cren in an aniujared condition, to insist upon the enormons top-heaviness which all this seems likels to impls. At anj rate, it is contrary to all naral science and all sea experience to so. build a ship as to forco its Officers, as a means of sccuring safety in the presence of an cucms at sca, to leave severul hundreds of tons of coal uudisturbed high up above the water-lice, and to take what they requiro from the lower bunkers alone. I will not put into language tho humiliation which I feel, as a naval constructor, at haring to witness and record such iucredible things as part of the practice of the British $\Lambda$ dmiralty, and actually put forward by the highest authority, not as a matter fraught with dauger, and to be decply deplored, but as a "compensating adrantage" for the loss of the abore-water armour-belt.

The third "compensating adrantage" which "some claim" is not the least curious of the threc. It is "that a shot, which during a roll might have struck below the belt, would, in its present lower position, be deflected." This is perfectly intelligible, and stated with admirable candour. It means this : that this belt has been made so narrow that if rou keep it up to its intended height above water, it may let shot and shell pass below it into the engines and boilers; and, therefore, when you hare suuk the ship down until tho whole of it goes under the water, so that she maj be herself destrojed ns casily as if she had no armour at all, then you get the compensating adrantage of preserring the engines and boilers from attack below the belt!

Such as they are, the seven ressels of this class appear to be the only belted cruizers which aro to be allowed to the British NarJ, unless the "Impérieuse" and "Warspite," which hare undergone various changes of desiguation, as well as of character, are again to be known as cruizers. They first appeared beforo Parliament as "armoured craizers" of 7,390 tons. They then appeared as barbetto battle-ships, or something of that hind, of $8,400^{\circ}$ tons, the increased 
tonnage being obtaincl by the simple device of orer-imnersing them to the extent to which their partial armour-belt was intended to rise above water. The "Impérieuse" having left our shores with the top of her armour-belt just awash, she is deemed entitled to renk again with the belted ressels as a cruizer ; and as an "nrmoured cruizer," and a "first class" one too, she, or rather her sister ship, tho "Warspite," again appears in this year's Nary Lstimates.

Finding no better results than the abore ensuing from their repeated attempts to prodnce "belted cruizer:," the Admiralty, not unvaturally perhaps, hare decided to try no more, at any rate for tho present, to produce anything so safe and serviceable. The 20-knot belted cruizers which I projected, and proposed to you in 1854 , have not been built, and never are to be built, rery fast belted ships being non decmed a luxury too great for the British Nary, and such as can only be allowed to other Powers to whom the combination of great speed and conl supply, with a fail amount of safety, is an olject of more carnest pursuit than it is with us. Not a single armoured ship of any description, whether cruizer or battle-ship, has been laid down for the Jritish Navy for more than two years past, and apparently none will erer he laid down again in this countrs nntil the public and the Naval Serrice take the matter into their orn hands.

It is not surprising that men who consider it a compensaling adrantage to being certainly sunk in one way that you lave not been destroyed in some other way, should get rid of armour alto. gether, and, haring entirels abolished it, should tell you that they aro building you "protected ships!" The "Blake" and the "Blenheim,"

Fig. 2.-Admiralty protected cruizcrs.

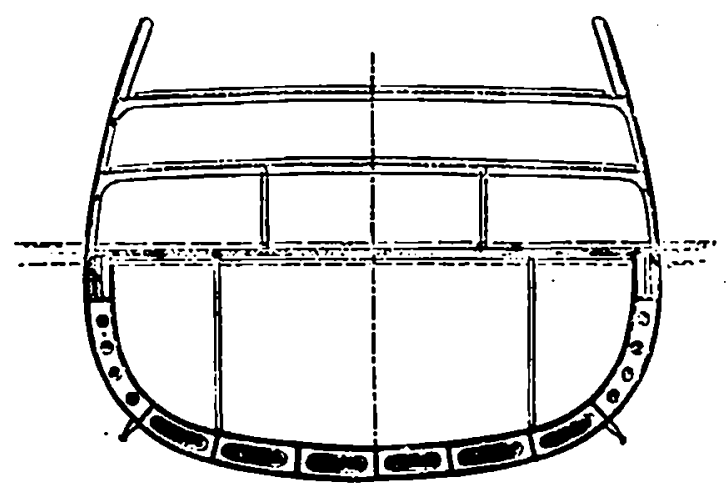

now to be built, are to be examples of this system; they are to be called "protected ships" precisely because, as ships, they will not possess any protection at all. Not a single inch of the surface of these two ships is to be protected eren against machine-gans. That is to be protected is the space bclow a certain stont deck and its 
contents, the said deck being itself ecveral fect under water. 'The machiuery and mnerazines will be protected against the fire of all guns of moderate power, and if the ship had been allowed the same alvantage, all would have been mell. But the ship itself, and its power to keep aloat, is not to be protected nt all, so far as I bnow, certainly not by stcel plating; and to my mind, at least, it is most extraordinary that men-any men, no matter who they are, or what offices they may hold-should be nllowed, not onls to deprive Her Majesty's ships of eversthing in the shape of protection, but then to parado them before us as "protected ships." Why the Nary itsclf does not demand the correction of this most mislending error I do not nuderstand. Llogd's ofticers have honourably refused to lend themselres to this, I see, in their inraluable "War. Ships of the World." Thes designate this description of ship as "deck-protected craizers," which, altbough not a wholly unobjectionable designation, is nu honest attempt to describe them in a manner that shall not be dangerously misleading.

Before leaving this branch of $m y$ subject I should like to lay it down again clearly, that the sacrifice of side-armour protection involres nothing less than the sacrifice of the power to keep long afloat under the fire of light guns. Give a ship a belt of arviour of proper length and depth, properly surmounted by a thick deck, and properly terminated, and she is perfectly safe against the fire of all guns that are unable to penctrate the armour-belt. Take away that belt, and substitute for it a low-sloping or curved protective deck, sach ns the "Blake" and "Blcnheirn" areI understand to have, and you at once offer her up as a viction to erers description of shell-gun down to the smallest. It is upon the inviolability of that rery triangle of buoyancs, so to speak, which you in this way sacrifice at the sides of the ship, that the stability and life of the ship depend; and to open this triaggle up to the inroads of explosire shell and of the sen is to sacrifice her. I wish the Council of this Institution moald take this matter up, in restigate it for itself, ard spenk out its decision to tho confusion of all who have attempted to mislead the Nary either was in this matter.

The question has been obscured by much idlo mriting, cspecialls on the part of those who aro either responsiblo for the deck-protected t5pe in our own Nary, or who aro engaged in building so-called marships for foreign navies, and who haro no particular interest in the consequences, so long as they satisfy their customers. But the facts of the casc are palpablo, and incapable of permanent perrersion. An armour.belt, of suitable depth, will keep out of the ship and amay from her rital contents not only all thoso shells to which her armour is proof when strack square, but likewise all thoso still louger shell, which striking obliquely cannot penetrate it. In this was an armourbelt protects the loating power of the ship against all the quick-firing machine and other light guns at presont atloat, and against many larger gans under ordinary conditions. In a ship with only a protecting deck orer the machiners and magazines, on tho contrary, all the shells of all these guns are receired into the interior of the ship, 
there to work any mischief of which by exploding theg mas be capable, and with the sea following in to occupy the space thus opened up to it. I say nothing of the "mellinite" shells, with which the French Navy is being supplied, and to which that truly gallant and patriotic young Officcr, Lord Charles Beresford, has so persistently inrited attention. I say nothing, for I feel that I need not say anything, as crery Officer present mast be aware that such explosiro projectiles freely used would leare but little chance of existence to our armoured cruizers with their submerged belts, or to our deckprotected ressels which are in a still worse plight.

Bat although utterly anfit to fight a close action with a belted ship, and running many risks of destruction from raking and other fire, the "Blake" and "Blenheim," by virtue of their enormous specd, 22 knots, will be raluable additions to the Naval Service. I havo not yet secn tho design, but from what the First Lord of the Admiralty said of them in Parliament, they appear to resernble in a remarkable manner tho ressel proposed by Sir William l'earce in 1883 or 1881, and rejected by the Admiralty Onice in no very ceremonious manner. 'They come nearly four sears after my proposnl at this Institution, to build belted cruizers of 20 knots. It is, nevertheless, a satisfaction to know that at last we are to have two rery fast ships, of somo sort, to ontstrip in speed the existing sca-going vessels of every other country.

I now wish to invite attention to the waste of public mones, as I cannot but regard it, which has taken place, is taking place, and is in contemplation in the production of ships of insuflicient speed. In and

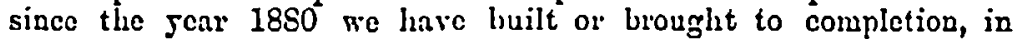
nddition to many other ships, tho following of which I give the nanes, the years of completion, the speed, and the total cost up to the 31 st Mlarch, 1887. 


\begin{tabular}{|c|c|c|c|}
\hline Niuncs. & $\begin{array}{l}\text { Tear of } \\
\text { completion. }\end{array}$ & $\begin{array}{l}\text { Utmost speed } \\
\text { in knots. }\end{array}$ & $\begin{array}{c}\text { Cost rougbly } \\
\text { stated: }\end{array}$ \\
\hline 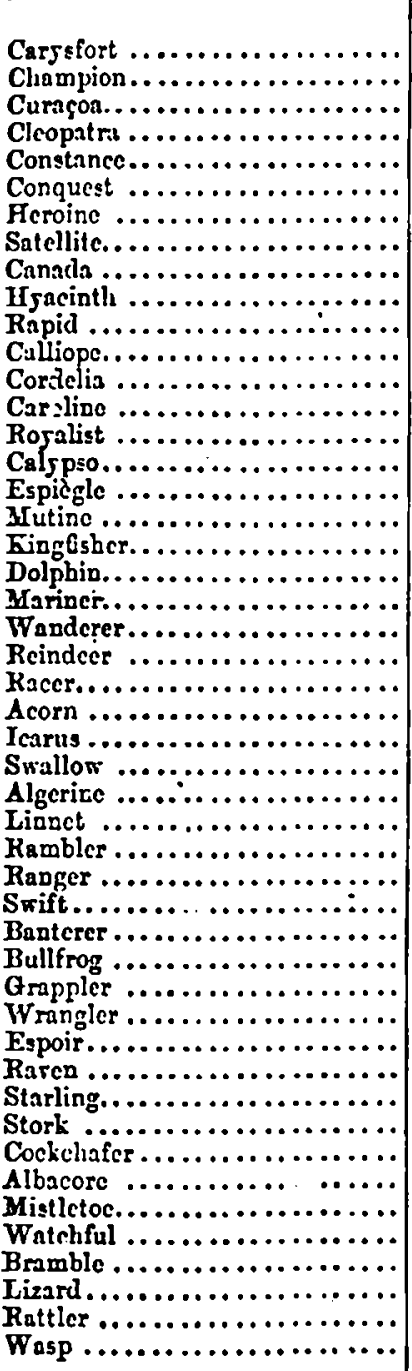 & 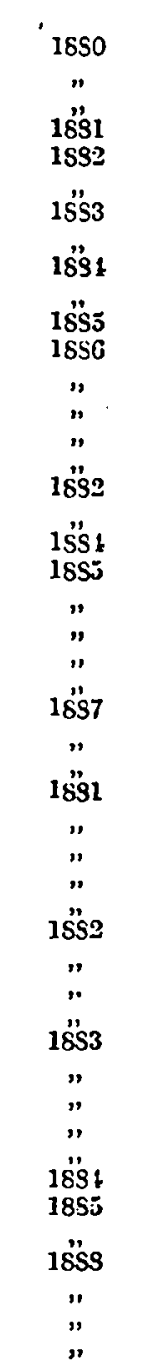 & 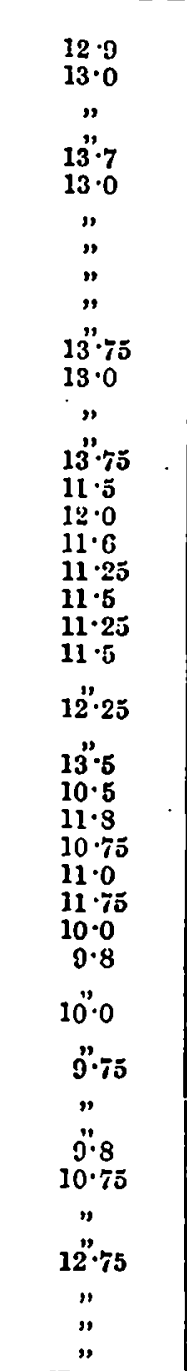 & \begin{tabular}{r}
\multicolumn{1}{c}{} \\
149,000 \\
139,000 \\
150,000 \\
140,000 \\
161,000 \\
141,000 \\
96,000 \\
93,000 \\
170,000 \\
96,000 \\
95,000 \\
190,000 \\
163,000 \\
106,000 \\
101,000 \\
209,000 \\
37,000 \\
95,000 \\
76,000 \\
51,000 \\
75,000 \\
52,000 \\
70,000 \\
74,000 \\
63,000 \\
72,000 \\
80,000 \\
57,000 \\
43,000 \\
60,000 \\
48,000 \\
12,000 \\
25,000 \\
32,000 \\
26,000 \\
31,000 \\
27,000 \\
25,000 \\
29,000 \\
25,000 \\
31,000 \\
36,000 \\
36,000 \\
35,000 \\
52,000 \\
66,000 \\
41,836 \\
39,857
\end{tabular} \\
\hline & & Total..... & $3,807,293$ \\
\hline
\end{tabular}


Uere we have nearly fifty vessels of war brought to completion in and since tho yenr 1850, costing nearly 4,000,000l. sterling, and while not one of them attained cren a measured-nile specd of $1+k$ nots, thirty-two of them fell short of 13 knots; one-half of them fell short of 12 knots; and some of them as low as 93 knots. Ninturally enough many of them are already condemned as useless for war purposes.

My object in drawing attention to them is to show how unwise our experience shows it to bo to lay down ressels of a speed which cannot be useful for war purposes should war arise. I am afraid that the very same crror is about to be repeated. In the Navy Estimates for the present jear provision is made for the expenditure of rery considerable sums of money npon war vessels of speeds which it is alrendy well known cannot be made available for war parposes. I take the following from tho Estimates for H.M. Dockyards and Contract Work for 18S8-89:-

\begin{tabular}{|c|c|c|c|}
\hline Names. & $\begin{array}{l}\text { Speed in } \\
\text { Enots. }\end{array}$ & $\begin{array}{l}\text { 'Total cost } \\
\text { (c:timusted) }\end{array}$ & $\begin{array}{l}\text { Iroposed erpendituro } \\
\text { for the year. }\end{array}$ \\
\hline 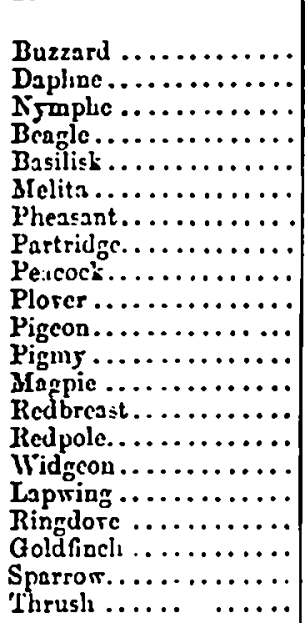 & $\begin{array}{c}1 \cdot 5 \\
" 1 \\
" \\
12 \cdot 5 \\
13 \cdot 05 \\
" \\
" \\
" \\
13 \\
" \\
" \\
" \\
" \\
" \\
"\end{array}$ & $\begin{array}{c}f \\
63,116 \\
63,0 S 2 \\
63,125 \\
61,000 \\
61,000 \\
61,619 \\
10,951 \\
40,93 ! \\
10,755 \\
10,712 \\
40,712 \\
10,712 \\
41,839 \\
41,839 \\
41,539 \\
41,000 \\
+11,000 \\
41,000 \\
41,000 \\
41,000 \\
41,000\end{array}$ & $\begin{array}{c}\mathfrak{E} \\
\text { (Tessel just completed.) } \\
17,155 \\
17,151 \\
\text { Not giren. } \\
23,233 \\
15,260 \\
16,629 \\
12,155 \\
15, \div 05 \\
13,895 \\
17,453 \\
25,311 \\
23,2.14 \\
23,014 \\
22,656 \\
30,024 \\
30,021 \\
27,697 \\
23,507 \\
28,507\end{array}$ \\
\hline Tot:s $\ldots . . .$. & .. & $1,001,295$ & 358,146 \\
\hline
\end{tabular}

Now I will not deny that there may be something to be said on behalf of some of these ressels, for something might be found to be said on bchalf of almost any conccivable kind of vessel in a Service so rast and complieated as the Nayal Service at present is. But I wish to take the sense of naral Oficers on the question, and to ask them whether, looking to the utter disproportion of our fust cruizers to the serrices which will be requircd of them in war, it is or is not wise to 
go on lavishing mones in this way upon ressels not a singlo one of which reaches a lij-knot speed, and most of which are to be of only about 13 knots at their very best, which means only about 10 knots in regular sea service?

The problem of defending the mercantile marine of this country in war time-and the defence of that marine is for us a problem so vital that the matters upon which Parlianent is expending its time and energy are, by comparison with it, trifles light as air-is one which, in my opinion lias not jet been mastcred, and indecd cannot bave been mastered, for the simple reason that the ninny able and energetic men who hare applied themselres to it roluntarily havo had to do so with bnt an imperfect knowledgo of official facts, while the official authorities bave not eren commenced, so far as we know, to organize a polics or a scheme for dealing completely with it.

One of the rery first questions which has to be dealt with is, what is to becomo in war time of the vast number of sailing ressels and slow steamers which form so largo a proportion of British merchant tonnage. 'The tables of Lloyd's Register Oflice furnish us with the following figures relating to the encrcantile marines of Great Britain, France, Germany, Italy; and Russia :-

\begin{tabular}{|c|c|c|c|}
\hline • & Nationality. & $\begin{array}{l}\text { Total } \\
\text { No. of steam } \\
\text { and sailing } \\
\text { resicls. }\end{array}$ & $\begin{array}{l}\text { Total } \\
\text { tonnage of steasn } \\
\text { and sailing } \\
\text { vcsscls ("ssiling" } \\
\text { nct, "st eam" } \\
\text { gross). }\end{array}$ \\
\hline & 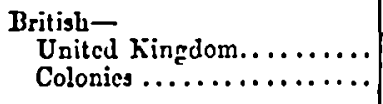 & $\begin{array}{l}9,091 \\
3,138\end{array}$ & $\begin{array}{l}0,127,45 \cdot 6 \\
1,434,141\end{array}$ \\
\hline & Total....... & 12,229 & $10,561, \overline{3} 9 \overline{\mathrm{j}}$ \\
\hline & $\begin{array}{l}\text { French } \ldots \ldots \ldots \ldots \ldots \ldots \ldots \ldots \ldots \\
\text { German } \ldots \ldots \ldots \ldots \ldots \ldots \ldots \ldots \ldots \\
\text { Italian } \ldots \ldots \ldots \ldots \ldots \ldots \ldots \ldots \ldots \\
\text { Russian } \ldots \ldots \ldots \ldots \ldots \ldots \ldots \ldots\end{array}$ & $\begin{array}{l}1,479 \\
2,056 \\
1,700 \\
1,229\end{array}$ & $\begin{array}{r}995,918 \\
1,387,365 \\
885,459 \\
430,300\end{array}$ \\
\hline
\end{tabular}

I have placed these figures together to facilitate other objects than that immediately present to our vicw. But hero we see that we possess, and haro to givo account in war time, in some fashion or another, of more than 12,000 steam and sailing vessels, but extremely few of which, cren among the steamers, possess anjthing approaching to high speed. Of mercantile and passenger vessels of 19 knots speed and upwards we possess but four, riz., the "Ltruria" and "Umbria," and tho two Chanucl stcamers "Victoria" and "Empress." Abore 17 knots and below 18 we hare fire only, and these aro all small, belonginis to the South Eastern Railway Company and to the London, Brighton, 
and South Coast Railway Company. Of ressels below 17 knots and alore 16 knots we have 12; chietly belonging to tho $P$. and $O$., tho Canard, and the Orient Companies. Of 16-knot ressels wo hare 11, of 151-knot 4, of 15-knot 23, of 141-knot 20, of 14-knot 39, of 131-knot 25, of 13-knot 46, and of 121-knot 30.' If, therefore, wo strike off from the total number of ships, viz., 12,229, theso 219 steamers over 12 knots in speed, we shall still leare moro than 12,000 ressels of which a few, the fastest, stenm only at 12 knots. Of these 12,000 resscls, 6,514 are sailing ships, of an aggregate tonnage, of $3,698,000$ tons; nnd the rcmaining portion, of about $6 \frac{1}{2}$ millions of tons, consists of steamers of 12 knots or less, the grent bulk of them probably aremging 8 to 9 knots nt sea. Taking ngnin Isloyd's figures, our' British merchant shipping is in itself rorth about $93,000,000 l$., and it imports property worth $349,000,000 l$, and exports property worth 269,000,000l. erers scar.

In riew of these mighty interests, and of the fact that at present $140,000,000$ l. worth of our imports are food, it is incumbent upon all of us to do the best re can to face and to assist in solving tho problem of its protection. One effectnal way of doing this will be to get all the money allowed by the conntrs and Parliament for tho purposo spent upon efficient ships. IFe havo seen how money has been recently spent upon ships which do not fulfil tho country's needs. Iet us collect a fow ill-spent amounts, including somo now contemplated :-

Expended on slow unarmoured ressels brought to completion between 1880 and 1888 , as set forth previously in this paper ................. $3,806,693$

Proposed cost of comparatively slow shipg now nnder construction or about to bo built.........

Cost of "Impérieuse" and "Warspite," whose armour is now under water at lond draught (including establishment charges) taken from Navy Estimates 1888-89.....................

Cost of seren belted cruizers in similar plight .... 2,000,000

$8,076,988$

This sum would havo secured to tho conntry no less than 16 20-knot ships efliciently armonr-belted, with rery largo coal supply (all as prerionsly described), and I rentaro to sag that whatever may be tho opinions of those present on minor subjects, there aro cxtremely few in this room who will not at once ncknowledge that, coald we at this monent cxchange the motley lot of craft previously

1 I takc tucse fgurcs from Llogd's Register Olice List, giren in their "War Ships of the World" ulrcudy quoted. They nro not apparently as complete as they wight bc. For crample, although most of what are bnown as our Channel steamers are giren, togcther with the "Lily," "Anglesca," and "Shamrock" of the Iondon and North Westcrn Kailwasy Companj, the "Ircland" und other steancrs of tho City of Dublin Steam Packet Company do not appear to be in. cluded.-E. J. R. 
enumerated for 16 ships of 8,000 tons each, such as I proposed to you in 1884, we should now bo able, not indecd to rest upon our onr:s, ov to ccaso to develop the war cruizer class, but to fecl that we had made sach a berinning as was in itself worthy of tho Nary, and was such as might fairly be expected to stimulate the naval prido and ardour of the countrs.

But the pressing matter is to see if naything can be dono in the wans of adrising or urging the abandonment of the slow ressels now commenced, or about to be commenced, in H.MI's. Dockyards. Some of them certainly could be stopped if desired, for in the Nary. Fistimates of the present jear they are set dorn as not yet ordered, and the cstimates of their cost bad not eren been inade. These were as follow :-

\begin{tabular}{|c|c|c|c|}
\hline & Namc. & $\begin{array}{c}\text { Tunaage } \\
\text { displaccusent. }\end{array}$ & $\begin{array}{l}\text { Speed in } \\
\text { inots. }\end{array}$ \\
\hline . & $\begin{array}{l}\text { Beagle................ } \\
\text { Basilisk } \ldots \ldots \ldots \ldots \ldots \ldots \\
\text { Widgcon } \ldots \ldots \ldots \ldots \ldots \\
\text { Goldfinch } \ldots \ldots \ldots \ldots \ldots \\
\text { Sparrow } \ldots \ldots \ldots \ldots \ldots \ldots \\
\text { Ihrush } \ldots \ldots \ldots \ldots \ldots \ldots\end{array}$ & $\begin{array}{c}\text { tons. } \\
1,170 \\
805 \\
" 1 \\
" \\
"\end{array}$ & $\begin{array}{l}\text { if·5 } \\
13 " \\
" 1 \\
" \\
"\end{array}$ \\
\hline
\end{tabular}

I kuow not low the matter mas shape itself to the minds of those who are here, but to ny wind it seems a deplorable thing to go on spending public money on craft like these, when wo know that our deficiencies in respect of fast cruizers aro deplorable when viewed in relntion to the work to be done.

In the "Daily Nerss" of 'Tuesday last is reported a conversation which appears to hare been recently held in Colombo with RearAdmiml the IIon. E. IR. Fremantle, U.B., the Commander-in-Chief on the East Indian Station. He is represented as having referred to a Russian ressel-of-ran that had recently visited Ceglon, and to bave said: "That is tho sort of ressel that would catch and take any one of my small craft, and do what sho liked with any one of onr post-captain ships, or 'correttes' as they are called. She could run arny with either of the correttes, and do exnctly whint sho liked with any others on the station. 'The worst of it is, ours are all an obsolete class of ships. We hare got more of the useless class of ships than any other European navy. The ships of which the Fast Iudian squadron is composed (eleven in number), in nddition to the tiag-ship, are all obsolete." The writer adds : "Admiral Fremantle declares himself 'a great adrocate of specd,' and asks what a naval commander is to do in time of war with ' horrible things that cannot go fast cnough to catch angthing or yu nwny from anjthing?" "I know not whether Admiral Fremantle used theso words; but whether 
lic did or not, it is ccrinin that they do not greatly, if at all, exnggernte our condition; and to my mind the only remedy for our defieiency in respect of fast cruizers is to induce the Aduiralts to put a complete stop to the building of slow ones, and to expend tho moncy roted by Parliament for cruizcrs onls upou fast and clicient ressels.

Adriml Bors : I shall detsin you bul one or two minutcs. I to not proposo to go into the details of this able paper of Sir Edmard Recd's; I vill onls eas generally. that mith reference to some of the statcincuts as put before the by the lectures, I fed bouncl to a arce with hin, but others appear to be so palpably inconsistent, that I camnot but think that tlice must be another vicw of the matter, and I hope thant gentlemen prescnt will join in the discussion, so that we was licar both sides of the question. 'Clicre is only one other ob:crrution I hitre to male, and that is as Cirairman of the Council for the jear : Sir Edward Rech sars, "I wish the Conncil of this Institution mould takc this mattcr up, ancl invcstigitc," de. Now I must point ont that by our rules the Council cannot undertule such an inrestigation. We as a bocls do not exferces our opinions upon the papers that arc react. I would al:o reminil members that tho Council do not hold thenesles responsible for any npinions th:te miay be cxpresicd in this theatre, and, as stalch on tho corer of the Jourmal, "suthiors alone aro risponsible for tbe contcuts of their respective papers." I now" Lope that we shall liare a full discusion.

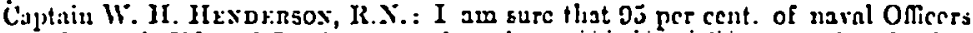

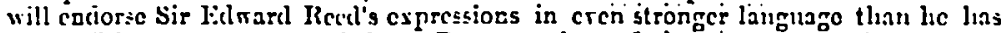
uscl. I liaso just come back from Portsmouth, and tho expressions that I liare

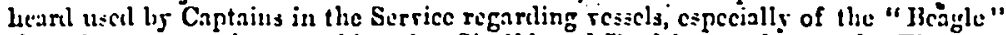
c'nes, is stronger than anything that Sir lidmasu Reed has malc use of. They eay tlagt they nre quitc.unfit for uny duts they may bo callecl upion to perform. With regurd to first-class cruizers, I certainls acrec with Sir liclward Hecl; I think thut. four belted critizcrs of $\$, 000$ tung would be better than the ecven 5,000-ton elij) that we liarc. With rcgard to the construction that has taken place since 18SO, I think the best mas of illustruting what Sir Filward hecd lias jut forkard is to draw attention to what Sir Gcofrey Hornly said the other day at the Mansion Ifouse.

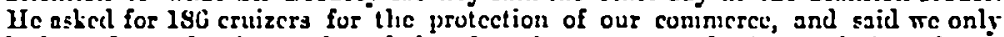
had +12 fit to do the work, and therefore that we wanted 1.11 resscls in order to cnsure proper protection. A greab nanyy people hare gono anay with the jelea tlast he askct for 14 adklitional slipps, aud hare said it is impossible to grant this. What lie rislly asted for was the rcconstruction of the cruizer class, simply because tho Aduiralts huro for tho last ciglut years aud more built ressch of inferior speed and coal-carrjing capacity. Just before I caunc down licre I counted in tho Nars Iist for this montle tlie number of sccond and thirl class cruizcrs nnt sloops ns DS; gunboats and gun-resscls, thiat is ec2-foing resscls (I am not including const. defenco re'ssls at all), ns 60 ; making a total of 167 ; so that, strictly epcaling, Aduniral Hornby wus only asking for an addlition of 10 cruirces to the puinber of rcsscls nom on the Ninsy Liat, the greater part of which should be fit to take their part in the protection of our comnicrce. If the 167 reszels tliat we non liarc ncro of suff. cient spect, ne should not now wnut tlis cnormous adlition to our Acet. Reconstruction was what lic realls nsicd for, not nddition. There is another thing rhich naval Officers are taught, nud thoroughly belicre: it is the lissons to be learnet from the nction of Iquique, between the Peruriuns and Chilians, on tho 21 st of JIas, 18ig, betweent tlic "II and the "Esmeralta" sloop and the."Corradonga" gunboat on the other; the deduction is, tliat if a gation builds sanall unarmed ships inferior in specl to ironclads, it must cxpect to lose them. That is what ne aru brouglit up to believe, antil jet Sir Edward liccd has pointcd out that resscls are continuously bcing built whicht are inferior in specd to the battle-slipj. Another thing rhich I rish to speali about is as to the ides of building resicls for peace serrice. Where it comes from I cannot eas : I can only imagine-I do not wish to be disfespectful-that some: Flog Oricers hare girce rise to the tradition in the past bs tring to clerute tho 
jeace dutics of stutions of which they hire had commanl ns of more importanco than the war requiremente of the uation, and consider that it is necessary to haro a certain slor resiscl to do the rontine peace dulics of a station. This is utterly absurcl. If sou posscss a ressel of specel nud conl-carrying capacity, slac will get round her stntion, will slow the flag, and will do, in proportion to hes specd ancl co:sl-carrsing culpacity, so wucle the enore work than a resscl of inferior powers. I wins recently in Austrilia, which is one of the most distant statious where we hare to beep the police of the ses in the Western Pacifie, whicil as jou all lnow is one of the most uncirilized parts of the eca. Wo had out there fire schooners, and nfterimards two others were sent out. Thesc scliooners could not do their work: they conld not get about. You had no means of getting communication with theill; thes covered very little distance. Strong representations rere made, and two gunboats were sent out, but I put it to naral Oflicers here, would not a decent stcamcr capable of going 1.4 or 15 knot 3 liare gone the rounds and brought constant intelligence and clone the work of that station rers much moro cflicicatly than those resscls which, directly they left the Flng Olicer's sight, mcro absolutcly out of control? I think tlic construction of the "13agle" class anchshe "Pheasant" class an utter raste of moncs. I liare beard naral Oilicers sas. "J3urn then," and ofluers say, "Throw them into the eca, for you minht just as well do it as build them." I do not want to take up the time of the mecting bs poing into the particulirs, but of the "Buzzard" class we hare five resscls built and building, costing 69,000l. cacl,, witit 1.4 lnots spect and 3,000 lnots radius of actiou, carrying cight 5-inch guns, and 16 ressels of tho "Pheasant" and "IRedpolc" class, costing about 12,0002 . cach, with 13 knots speed, and 2,500 lnots radius of action, and mounting six 4-ineh guns, making a total expenditure of orer a million, as Sir Fidward Recd has stated, and on ress:ls inferior in specd to the battle-slip specd of the d:ly, and ob:olete in their inception. I must inform Sir Edrard that the "lBcagle" is well uneler weigh nt lortsmouth; it is too late to stop her construction; she will bo ready for lowing out of doek before rers long. Faral Oficers say that none of these rcsicls eliould be inferior in spced to the battle.ships, and to say that rcsscls of the requircl specl cinnot be built is prepostcrous, because no aro builiting torpedo gunboats rith a specl of from 10 to 21 knots, and with the eame radius of acticn of 2,500 knots. I look upon this million 232 sliecr raste of mones. Coning to the sccond-class cruizers, the " Ifelea" class, I wish to say a word on which naral Onicers fecl rery stronglr. Those resscls are 265 fect long; ther liare 2,950 tons slisplacement, 9,000 lior:c-power, c:trrying 100 tons of coal; thes liave 8,000 knots as their radius of action, aud carry six 6 -inch guns, at a cost of $15 \pm, 000 l$. apiece. Tow crers naral Onicer and crery eapiain of a steam merchant ressel, or indecel nuy Eailor, would tcll you if you capect a ressel to kecp the sea and mako a jissanc, sho must not be less thinn 300 feet loug. IVe can all sec these resicls 260 feet long are too short; thes should hare been mado longer without increasing their arnjarnent. This jueresse of length would hare made then efficient ressels, and by enabling an increase to their coal supply, would nisto up for their great deficit.? The test of a sccontl-class cruizer sliould be that slic should rcally be able to go at the eame epecd as the "Unbria," 19 lnots; that she sliculd be practically ablo to steasn acros 3 the Atlantic with the best of our fast mercliant steancrs. With regard to the "liarrosa" and the "Barham " class of ressels, the "Barrosa": class comprises fcur vesicls of 1,5SO tons cacl, 3,000 horec-prorer, a speed of $16 \mid$ bnots, and a rarlius of action of 3,400 milcs, carrying sir $36-p)$. quick-firing guns. The "Barhain" clas3 hare 1,800 tons displacement, 5,500 horse-power, a epeed of $19 \frac{1}{2}$ lnots, but onls a radius of action of 2,600 milcs. Those aro third. class cruizers, and again there is some discrepancy, sometling wrong here; $19 \frac{1}{2}-b_{1}$ ressels, with only 2,600 knots radiuz of action. Fe say that sccond and third class cruizers of the prescat time should have at least 191 . knots speed with the greatest

1 One great defect in the stcaming power of all men-of war is diliculty of coal supply to the furnaces, consequent on its distribution for particular purpos's orer eo much of the length. This defect will nerer be satisfuctorily reusdical until increase of length chables large coal bunlers to be placed riglit across sbips on each side of and between the sets of boilers. 
radius of action rou can gire them. I think $\mathrm{ke}$ all consider that epeed is of the rers greatest adrantago nossible; speed and coal-carrying capitcity aro the two prime elements necessnry for cruizers, becutse when a resecl has superior spect she lias the power of trging lier gun-firc, of using lecr torpelocs, and of rnmning, while a ressel of inferior epeed has no clioice in the matter.

Mr. BADrs.l'ower.L: It sccms to me that tho qucstion of fast cruizers is n rital onc. Sir Edward Reed, ns I understand, proposes a speed of 22 lnots. I sliould like to know how war-resscls are going to be built to be able to kecp up a specd of anjthing like 22 lnots with the coal capacity which thej nt present hare. I hare seen orer and orer again large mereantile resscls coal, and know that the arcrage consumption of an $\mathrm{A}$ tlantic liner is from 250 to 300 tons crery twenty-four liours. Fow if rou tako a resscl to a distant station it stands 10 rcason that she must bc capable of taking in not onls 1,500 tons of coal, but 1,000 orer that, in order to cnable her to get out to her station. That is a point which I think has not becn duly considered in the construction of the cruizers which the Almiralty hare becn building, and it docs eccm appalling to me the small amount of coal capacity allowed for eruizcrs. There is another point that struck me very forcible, that was that the lecturer has not mentioned how these ressels should be riggel. I lnow that there are nautical men who sag that a figliting battle-slipip should not haro masts and sails. At the Naval heriew last year, and since, we hare ecen many of these cruizcrs riggrd only rith small jury masts, and an apology for a foresard; lior are these resscla going to kcep on their station? Are flicy going to cat the cosl tho whole timo thes are out on the station? Are they going to eat their coal on the was out, and then hare to fight on an empty bunker? "ilicy c:unnot do it, they would be captured directls. I should like to know whether the cruizers that Sir filward Keed proposez are going to be fully rigged so as to be able to beep the sea under sail; with possibly some inrention of Sir F.dirard Recd's for starting fires in a lutry (like tho steam fire eugincs do on sliore), to promptls fet up stcam when the enemy licares in siglit, or is reported to hare been discorced; but otherwise to kecp the station in the old style under sail. These are important questions with regard to cruizers; one affects ilie question of our coaling statious, nnd the other nIfects the question of kecping ecamen as ecamen; I think thes are of great importance to the country. There is oals one other question that struck ine rers forcibls with regard to cruizers; I can scarcely beliere it to bo true to say that naral architects in cliarice of the construction of ships can go and immersc those ship) in the raj that Sir Echrarl llecd sass thes do, can fo and put slanting armour dechs below an unprotected mater-line, which, if the eides are penetrated by quick-fring shell guns, umst produce such a capsizing influcnce that the ressel will be in such circumstances utterly unscamorthy. I hopo Sir Fiward Reed has not been telliug us jarns : tre are not marines."

Cuytain Curris : Perhaps Sir lidwart Reed would enlighten us a little more on this subject, about the 4 feet of ammour in his proposed cruizers, because one would imagine tlat there was 4 fect of armour nbore water. Ue says, "The cruizers rould liare largo thick belts, rising \& fect nborc water, all wlong the broad ccntral parts of the elip." Fcrlaps Sir Fidwarl Reed will crulain whica the resecl is imasersd in trim for aca, hon much armour is abore water, and also liow much urmour is abore water when the ships are light, saj with 50 tons of conl on bonrd. I bare licard Sir Niathaniel Barnaby lecture on lis ships referred to herc, and he

I Inderstand one of the assumptions in the Admiralts design-midship scetion of which was cxhibited bJ Sir Felward Hecd-wns that the welge spuce of vings aboro the slanting armoured deck were to be filled with conl as a protection, and lept full. But for a cruizer uiany dajs out on licr station, and probably coming inlo action after a long full-speed chase, unlcss tho coal below bas been used first, which is rers unlikels to bo tried by sailore, though casily suggested from a chair on shore, the wing pockets might cnsily. bo filled with water when rounded. The case miade out in the lecture simply reninds one at once of the almost sinilar conditions which capsized the "Austral," in the smooth ratcr of Sjdney liarbour. A lopsided deck lias poor mancurring powers, and eren if no worse happened than a licars list, all brosdside guns rould be thrown out of action.-W. B.P. 
stated liis ressels were designed to carrs about 400 tons of coal, and the authoritics placed 100 tons ou board, which fulls accounts for the inmersion of tho armour. 'lihe with recrard to the armour itsclf, I liare stated before in this Institution that I hare scen at finburn a epar that a 69-pound shot fircd from the "IIannibal " had pissed through, the nperture had cloaed so small that one could not put his finger through tho hole. Fow it scens to me that wood of this hind night bo placed outside these shipe. Formerly we used to place iron out side the old rooden ressels, but if son place rood or moodite outside the iron it miglat act as a protection agninst leakisg, and then as the ship gets more immerecd, instead of getting lezs buosancs thes will bare nore. It secms to me that if you were to penctrate a ship with a shot, the specific gravity of coal being ereater than thiat of water, the coal would go out, and the water would come in. The result would be that the ship wrould hare mother an awhmard list on the opposite side, nnd the guns rould be out of action. You might just as well put water-casks isside a ship to gire her floating power, if sou anticipate anj buojancs from under the armour-deck, as it appears to bo: Aush with the water-line. I would suggest that perhaps wo inight find somo was of protectiog ships by some ofher substance instcad of iron, comething in the may thes are non doing it, by sheuthing outside. I might also mention't that when the inain topgallant mast irent through three of the "Jiarlborough's" decks, tho Oftiess suid he could not put his finger through the holes. 'That is another instance of the wood closing up after penctration; u hole has been made tbrough it.:

Sir E. J. REED : I feel rers thankful to Captain IIenderson for being good cnough to cone and ansio tho statements that he lias inade, bccauso thes nre obriousls in furtherance of the ain that I hare in riew, and which, I hare no loubt, naral Otlicers present liave in vieur. $A s$ I think, oving to a slight want of clearness on one point, there might possibly be soune misunderstanding, I should like to ask Captnin IIenderson if I understood him aright as 10 Adwiral Hornls's riews. What I think lic secmed to say was that Admiral IIornbs did not propo:e to add 167 cruizers to the cristing Navy, but what the Adwiral neant was that lic should sequire the totnl number of cruizcrs which lic stisted, and that had the ships we posscas been built of proper speed, then wo should only hare requiret about 19 unore to bring our Nary up to what he cunsidered necessary. You do not mean to imply that, liaring such resscls as we bare, 19 cruizers would bring up our Nary to what it should be?

Captain IIExdersox: No.

Sir E. J. RE:D : I understood jou to sag that if the Goremment had preriously built efleicnt ships, we slould now baro required to uset deniral Horubs's ricirs only 19 additionsl ships.

Captain UEx Dxrsox: 'That is 80.

Sir F. J. ReEn: I think Mr. Baden-Porell touched some rers practical points. With regarl to tlic ressel of 22.knot specd, I presume it is quitu understood that the object of giving thoso high speeds to mar-ressels is not that they may under nny condition trarerso larger ocenn spaces at that cnormous relocity ; the object is, I apprelsend, that whilo they perform this ordinary serrice with cflicient epecd, thes Elrould hare tha poncr, when the neceseits of orerhauling an cnems comes, of complying witl, that necessity. And onc of tho things that cacourages me more than nuy other to urge the production of rery fast ohips is :the etriking cconomy with whicl a very fast ship will go slowly. I hare had occasion latcls, in designing somo ironclad cruizcrs, to go into that rery carcfully, and I find that with sueh a sped as srould be suffeient for a ressel in procecding under ordinars circumstances to a furcign station, thes can carry coal cnough to go about 14,000 knots, and I mssclf thint that eren a supply of coul which would cuable ressels to cross the Atlintic, eas to go to the United States, at a speed of 14 or 15 knots, would be sufticient for the ordinars purposes of the Rosal Nary. IBut I agrce with Mr. Baden.Powell entircly in crpressing astonibliment at tho coal supply of recent ships. One vould

1 This occurred in Sir William Parter's commission.

2 Fo doubt in erent of war theso cruizers could hare fittings outside, 50 as to corcr ang holes by penetration by placing plank slecathing; it appears quite fcasible. 
lare supposed that, with this increase of specd, the necessits for winich has becu brought hone to us, we should hato mado erery effort to go on increasing tlic coal Eupply ; but instcad of that the characteristic feature of the modern fast ressels is that thics barc ecarcely any coal supply at all. Now the ground of all that, or the excuse for it-for I cannot put it nnj higucr than that-the cxcuso is the cconomr of the triple cxpansion engine; but then the utmost differenee that oun can anticipate in the consumption of fuel as betrecr a good compound engine and a fool triple expansion engine, is about $\frac{1}{3} \mathrm{lb}$. of coal per horsc-poner per hour out of the $2 f$ lbs. a compound cngine will consume. A trijle expausion engine will run upon lis los. per horse-power, wheress a conipound requircs $2+$ lbs. That difference is not so very large, and cannot possibly be made to justify the recent large reductions iu the cosl suppls of Her IIsjesty's ships. And Jet what do wo ece? We saw that in the case of those belted cruizers when the porrer was sent up from 7,500 to 8, 000 horscs, tho coal supply was reduced from 500 to 450 fons, and there we were with cngines of 8,000 liorse-power-about three or four tinies the hores-power of the old line-of-battle ships-nith 150 tons of coal! Captain Curtis rery properly pointecl out that the state of those ressels has been-not wholly, I inay sas, but rers largely-brought about bs the fact that the present Board of Admiralty liare insistcd on putting into thesc resscls a larger coal supply than usas contemplated.

Captain Ce ntis : I wished to cxoncrale the naval architect.

Sir 1. J. Rr.r. : And tliat docs largely csoneratc the naral architect. It is a rery delimte matter for me to discuss the responsibilities of naral architects, but what I eliould $s 25$ is that I rould risit upon ang naral architect this measurc of responsibility in the mitter: and I would ens crery naval nrehitect ought to remember that an arnour-belt of ouls $\delta_{2}^{\frac{1}{2}} \mathrm{fect}$ in width is a sham belt and not a real our, and docs not gire you the porrer of meeting those many contingencies which besct ship-orning and ship-rorking; aul, thereforc, the couplaint I would unke against the naral arclitects of the $=\mathrm{c}$ resse $]_{3}$ is this, that when it had becn stated by another maral architect (mysclf) in this hall, that a ship to steam nt the high speced that mas desired, to carry a larye coal supply, aud to hare an eflicient belt, required to be a elip of 8,000 tons-a statement which was not at all conicsted licre-thiat they should jiare ect themsclecs up ns so much cicrerex than other people as to go and produce a ship of 5,000 tons, nnd pretend that nith that ressel thes could accomplish thic object. TJiat is where I blame them. $A$ naral architect should hare known that 8,000 tons was necessars for the specd ained at, for the cosl supnly desired, and for the cfficient belt. I must eas it is a rerg unfortunate thing that ans boly of gentlemen - naral urchitects os naral Odicers, or ans of lice responsible persons in tho Adiniralty-should hare placed tho present Hosrit of Aduiralty in the position of cither haring to ecnd these ressels, seren of them from our ports, with this cnormous horse-power for their size, and with a ridiculously cmall coal suppls; or elso should hare to accept the other altenatirc, ranels, putting in a rejsonable coal supply, and sculing them out with thcir catire armour below water. I do not think we can quite reliere the naral architects of responsibility because thes tricd to do, or thes undertook to do, what the lawg of nature nnd the fncts of ecience both would hare sliown that they could not do. Ilowerer, I mas sas that this matter is quite incidental. It is perfectly true, as I liare statcd in this paper, that I nerer lave allowed mysclf at ung time to ciril alout. enall questions, cr to discuss any minor shortcousings in IIer IIajesty's ships. I think anyone who bnows the circunstances will know that a man who has been fourteca scars in the llouse of Commons, if he had had the displosition to agitate upon small shortcomings, would haro had hundreds of opportunitics such as I certainls hare not arailed myeclf of. All I bare crer tone lias bcen to endcarour to put a stop to some crt raordinary riolation of common sense, and I an rery glad to liare the testimony of IIr. Biden-Porell to th.e fact that lic can liardly understand any naral architect approrino such arrangements ns I liare referred to. Well, that is preciscly my difficults. I Foon that the naral architcets arc sane, and that thes do propose these things; but how, being eanc, they do propose them, and persist in them, is a problem which $I$ am quite unable to solic. I can onls eas that in my judgment the largest danger to this country is due to the fact that sowo 
of these unaccountable things lare been done. There wins a time when one was finhting the up-hill unttle of condemuing the "Admiral" class becnuso of their cxircmely limited surfaco of side armour. All necessity for that bind of eftort is now gone, when wo know, when you gentlemen know, when tho world bnows, that theso [pointing to the belted cruizer with submerged armour, and to the deckprotected cruizer, with her defeusire plating also submergenl] are the sort of things to which the lind of adriec ncted upon of late years has brought us to. All tho armour is put below water in order to carrs eren a moderate supply of coal to sea. When you ceo these things, you will, perhaps, think there is some ground for my nupreliensions in the cusc of other resscls, although their armour mas not hare been put entirely out of sight. I would like to say one more nord upon the question of conl supply. What I do not understand is why tho conl suppls has been lept down as it is; because nothing is more common in designing, nothing is moro the daily experience of sen cogaged in the profession that I beloun to, than the proof positive that some increase in length of ships and coal. carrging dew's not impose licary penaltics upon sou in the rray of the construction of ship or of construction of power to drire it. When rou line got those long finc-linel ships, you can rers well afforl to put a short length of iniddle body in in the niddlo of jour cruizer. lsut unfortunately we haro gone upon the opposite s5stcm, and maling crer-incressing demands upon the ships' speed, we liare taken the coal out of them more and more. 'Tliat is not all. IIr. badch- 'owell has drairn attention to another thing cqually unaccountable, and csictly of the eame nature, and that is, that hasing crippled now paralgzed stcam slips for waut of coal supply, we liare also taticn away from them erery posibible means of helping themselres along by sail. I should be very sorrs to express any strong opioion on the rigging of cruizers in the presence of Ofliecrs far roore able th:un I to gire an opinion; but I will s.as this, that when the line-of-battle slip "Dcrastation" mas designcd, I did not hesitate to deprirc her of sail power. I hare nerer been able to understand, and $I$ do not now in the least understand, why theso fast cruizcra are depriscl of all sail porrer. I am quito aware that it is casy to show what a long way a elip can go on a rers sinall suppls of fucl; but whit males me feel the difficulty a little more is this, that while we hare taken out all masts and sails from this class of resscls, we hare not taken away the seamen who are to vork them; but to uy surprise I fiul that the "Orlando," a resscl of this class, lans no less than $-15 \mathrm{~S}$ Officers and men. Had she possessed somo measure of sail frower, she would not bare requirch additional men. I stato that with gre:tt confidence, beciuse I hare compared her complement of Oatecrs and men with the complement of uship that carries considerable sail power, und sho has the samo number within five : therefore she bas a complement for morking canras if alie hacl it. Captain Curtis drew attentiou to the probability of being able to assist a ressel with thin sides by emplosing wool or woodite or some other like material on the outside, because of tho property which it posscses of closiog up again. The difliculty I think in that malter is this, that the reason that an clastic substance lite rooditc, or nood, or s3wn fir closes up again after the sliot has gone through, is that it is able to jicld more or less to tho passige of the shot. And if it nere a shect of roodite fired at, I npprehend the shot would tcar its was through, the woodite yielding, and Aging back into its position ana closing up, beeanse wlıt mould hare been made would be not a hole but a tcar. But if you put that sheet insicle of a plate, and tlien fire at it, jou will make nct a rent but a hole, because jou will punch ont the piece, and it scems to me the conditions of un elastic sub. stance, backed by a rigid substance, are those which would deprire the clasticity of the opportunits of doing its work. I fecl that didiculty, but at the same time I wonld point out that collulosc, which is being a good deal used in tho French Nars. and is praised hy French designers, is not used outside but inside, ns wooditc should be, and it has been proved by experience that when jou put that inside, and a shell or shot passes through the plating outside, and then througin tho cellulose or woolite, the ccllulose or woodite closes up afterwards, and beeps a griat deal of watcr out. I um not a opponcet of anj derico of that kind. But what I ain an opponent of, is the subititution of any derice of that bind for effectual modes of becping out shot and shell, sas tho substitution of celluloso for stecl annoir, and 
then for those who haro macle the substitution to hase the effrontery to tell tho world that thes hare "protected" ycur elip. In conclusion, I maintain that nothing lias happened among us to nulie me hesitate for a single moment to beliero that this country can perfectly well afford, and ought to expend, whaterer nones is necessars for producing the vers ships that it desires and that it ought to have, and I do not believe that either common sense or any true epirit of economy has ret lriren us either to inclia-rubber, or cellulose, or fir, or nnything of the bind in substitution for the trustirorthy defence of etcel arnour-plates, which we know cannot be penetrated bs the minor armanents of the enenis.

The Cratruss: It onle remains for me (and I am eure you will wish me to do so) to thank Sir Fdnard liecd rery cordially for his paper. It la:s not liad the efrect of producing a long discuseion, but the remarks from Captain IIenderson and Mr. Baden-Powell and others I an sure hare clicited in the repls a still greater amount of raluable information. I do not think anything can be more certain than the closing remarks Sir Fdward Recd made, that nothieg sliould induce this country to grudgo ans amount of pioncy that is nccessary to produce the most perfect ship, wbether battle-ship or cruizer, that ecience has shown can be produced. 